\title{
Sergei Dovlatov's Ludic Literary Discourse in the Original and in English Translations
}

\author{
Evgeniia M. Butenina* \\ Far Eastern Federal University \\ Ayax Bay, Russky Island, Vladivostok, 690920, Russia
}

Received 09.01.2016, received in revised form 10.03.2016, accepted 18.04.2016

\begin{abstract}
Russian émigré authors created numerous postmodern ways of mediating Russian classics into contemporary fiction. Many scholars discussed Vladimir Nabokov's role in this phenomenon, while such third wave writers as Andrey Sinyavsky/Abram Terz, Vasiliy Aksenov, Sergei Dovlatov continued and developed this tradition. The paper discusses Dovlatov's ludic literary references in the original and shows how his three translators, Ann Frydman, Antonina W. Bouis, and Ekaterina Dovlatova, rendered them into English. While Sinyavsky's books already found direct response in American fiction, resonance to Dovlatov's stories is likely to occur in Anglophone Russian American literature, thanks to (re)translations and other popularizing projects.
\end{abstract}

Keywords: third wave emigration, Sergei Dovlatov, The New Yorker, Ann Frydman, Antonina W. Bouis, Ekaterina Dovlatova.

DOI: 10.17516/1997-1370-2016-9-5-1232-1238.

Research area: philology.

\section{Introduction}

In the late $20^{\text {th }}$ and early $21^{\text {st }}$ centuries world literature witnesses a boom of postmodernist interaction with Russian classics, which includes fictional biographies of Russian writers as well as numerous literary updates and other allusive forms. This phenomenon is especially noticeable in American literature thanks to the mediation of Russian literary discourse in Vladimir Nabokov and the third wave émigré authors such as Andrey Sinyavsky/Abram Terz, Vasiliy Aksenov, and Sergei Dovlatov. Dovlatov achieved an unprecedented success for an émigré author in the United States as the elite weekly The New Yorker published ten of his short stories between
1980 and 1989. This paper demonstrates how Dovlatov's translators rendered his ludic literary references, which create one of the key features of his (auto)mythological poetics.

\section{Sergei Dovlatov in The New Yorker}

The New Yorker published stories from four of Dovlatov's collections: "The Jubilee Boy" and "Somebody's Death" come from The Compromise; "Straight Ahead" is the last chapter in The Zone; "My First Cousin", "The Colonel Says I Love You", "Uncle Aron”, "Uncle Leopold", and "Father" are from Ours; "The Photo Album" and "Driving Gloves" are from The Suitcase. ${ }^{1}$ Katherine T. O'Connor and Diana

(c) Siberian Federal University. All rights reserved

* Corresponding author E-mail address: butenina.em@dvfu.ru 
L. Burgin translated "Somebody's Death", Antonina W. Bouis translated the two stories from The Suitcase, and Ann Frydman, whom Dovlatov met through Joseph Brodsky and often called his coauthor, introduced him to the magazine and translated the rest of these stories. Frydman also translated The Compromise, which became Dovlatov's first book issued by a major American publisher Alfred A. Knopf (1983). Several popular periodicals, including The New York Times and Harper's, reviewed The Compromise favorably, and Slavic scholars particularly praised Frydman for carrying over Dovlatov's "sense of rhythm and repetition" (Feine, 1984, 553). In 1985 Knopf published The Zone in Frydman' translation and in 1990 Weidenfeld published The Suitcase in Bouis's translation. Thus, The New Yorker opened a gateway to a wider literary American scene for Sergei Dovlatov.

Half of the stories published by The New Yorker tell a semifictional story of Dovlatov's family, which he framed in ludic literary allusions. In "Uncle Leopold" he introduces his father, Donat, and his two brothers, Mikhail and Leopold: "U moego evreiskogo deda bylo tri syna. (Da ne smutit vas eta obmanchivaya bylinnaya nota)" (Dovlatov, 1995, 169) (My Jewish grandfather had three sons. (Do not be confused by this deceptively epic note)). Frydman simplifies the author's remark but adds the place of the sons' birth, perhaps for a folklore effect of a reference to faraway lands: "My Jewish grandfather in Vladivostok had three sons, just as in a fairy tale" (Dovlatov, 1987b, 25). Dovlatov's goal is to embed the tragicomic history of his Jewish ancestors into Russian cultural history. His translator compresses the tragic part such as the comment that the name Mikhail is an omen to early death if we remember Lermontov or Bulgakov and the fact that the narrator's uncle died in Leningrad under siege.
Sadly, even the comic part is sometimes distorted: for example, uncle Mikhail sent his immature poem with a line containing an idiom razbit' lob (beat one's brow) to Mayakovski and in reply received a put-down proverb with this idiom. In translation this play on words is lost due to the use of two different word combinations: the proverb «A fool prays to God and ends up cracking his skull» does not evoke the line «I was a-tremble, and I yearned / To beat my brow against a wall, to fall...» (Dovlatov, 1987b, 25). Similarly, Frydman omits the narrator's comment on the "literary" background of his second uncle, Leopold, whose zamorskoye imya (overseas name) seemed to anticipate his cosmopolitan adventurous biography that reminded of Mayne Reid's and Fenimore Cooper's heroes (Dovlatov, 1995, 169). Perhaps, these authors, beloved in Soviet Russia, are long forgotten in English countries and this allusion would not have a similar effect, or the comparison of the "swindler" uncle to Anglo-American literature characters could somehow be politically incorrect, but in any case these compressions pose a doubt to the adequacy of the translation.

The literary origins of the narrator's relatives remained complete in Frydman's translations when they corresponded to western stereotypes about contradictory Russia. The narrator says that his father "looked youthful and elegant and yet at the same time like someone out of the "Lower-Depths" flop-house. He looked like a cross between Pushkin and an American on unemployment" (Dovlatov, 1987a, 34). The narrator's first cousin reminded him of "Levin in "Anna Karenina". On the eve of his marriage, Levin lamented that he had already lost his virginity in his youth. My cousin tormented himself with a similar problem - namely, how one could be a Communist and have a Criminal past" (Dovlatov, 1983, 52). Both remarks sarcastically contrast Russia's aristocratic past symbolized by 
the names of Pushkin and Tolstoy's autobiographic character with its present in "lower-depths", either impoverished or criminal.

Frydman also preserved Dovlatov's expressions of half-hearted antagonism to Soviet system, which often reveals in his selfmocking references to worshipped socialist texts. In "My First Cousin", he fears "sounding overliterary like Sholokhov's 'Tales of the Don'” but immediately comments that in his uncle's speech he "could detect motifs from Gorky's 'Song of the Falcon"' (Dovlatov, 1983, 52). In "The Photo Album", he laments that his wife randomly made her reading choices and "always ended up reading good books", but when he attempted to do the same "it's sure to be Plowing Virgin Soil" (Dovlatov, 1989b, 45).

Like Anne Frydman, Dovlatov's second frequent translator Antonina W. Bouis also took some liberties as if she were his coauthor. While she preserved the quoted literary reference in "The Photo Album", she distorted a comic Pushkinian strand in "Driving Gloves". In the original, the narrator tells of his attempt to play Peter the Great in an amateurish film by Yuriy Schlippenbach, who has a habit of quoting Pushkin's reference to his heroic Swedish ancestor in "Poltava" poem. Bouis simply renames this character to colorless Filimonov (Dovlatov, 1989a). To her credit, in 1990 she translated all stories of The Suitcase short story cycle, and this version, edited by Ekaterina Dovlatova, is truer to the original. In this particular episode Schlippenbach proudly "barks out" Pushkin's lines when "the fiery Schlippenbach is taken,/And Rosen leaves the field of blood"(Dovlatov, 2011, 114).

Overall, both Anne Frydman and Antonina W. Bouis compressed and simplified Sergei Dovlatov's ludic literary discourse in their translations for The New Yorker, and the magazine's readers were able to appreciate his universal humor but not all of his comic references to Russian literature. The recent trend of retranslations and new translations inspired Dovlatov's daughter contribution to her father's revival in the English-speaking world.

\section{The Dovlatovs' Pushkin Hills}

Following her editorial work, Ekaterina Dovlatova successfully tested her own translation skills. In 2013, Alma Classics of London and in 2014 Counterpoint of Berkeley published her translation of Sergei Dovlatov's famous and perhaps best book Zapovednik (originally published in 1983). The translation gained high praises: The New York Review of Books reviewer states that “Katherine Dovlatov's translation feels almost transparent at times, as though the original Russian were visible through the text", while Rachel Polonsky of The Times Literary Supplement believes she "brings into English her father's gritty mix of elegy and wit." The famous American novelist Francine Prose expresses a universal feeling when she says that "One wishes that he'd lived longer, been published sooner, given us more" (Praises for Pushkin Hills, 2013).

Ekaterina Dovlatova renamed Zapovednik to Pushkin Hills since the English word "preserve" does not have a meaning of a museum-estate, "which is a very Soviet concept" (Stivers, 2014). While in the quoted interview with Valerie Stivers she calls the changing of the title her first translation failure, this seems not to be the case, as it helps Anglophone readers to identify the book as Dovlatov's key Pushkinian text. Ironically, some reviewers notice that the narrator is a "classic example of that distinctly un-Soviet figure, the "superfluous man", popularized by Turgenev and Lermontov" (Taplin, 2013) and omit the fact that Pushkin opened this "gallery of superfluous men" in Russian literature with his Eugene Onegin.

In Zapovednik Dovlatov's autobiographical protagonist, an unpublished author, comes to 
former Pushkin's estate to have a break in his complicated Leningrad life and to work as a summer guide at Mikhailovskoye. As many critics noticed, in this book Dovlatov attempts to revive the original Pushkin degenerated by the Soviet officialdom. To mock this bronze myth, he contrasts the pomposity of the museum's guides and the parodic Pushkinian features of the reserve and its dwellers. The guides jealously and suspiciously ask the newcomer why he loves Pushkin, and he tries to be tolerant to their weaknesses, thinking: "Everyone in service of the Pushkin cult was surprisingly begrudging. Pushkin was their collective property, their adored lover, their tenderly revered child. And any encroachment on this personal deity irritated them" (Dovlatov, 2014, 35).

These servers of "the Pushkin cult" were no less parodic than the local waiter with his "tremendous felted sideburns" (Dovlatov, 2014, 5), as if caricaturing numerous Pushkin's portraits, whose similarity with the poet was also "confined to the sideburns" (Dovlatov, 2014, 22). Self-ironically, the narrator compares himself to Pushkin since the poet "too had debts and an uneasy relationship with the government. Plus the trouble with his wife, not to mention the difficult temperament" (Dovlatov, 2014, 107). Creating the appropriate environment for his self-identification, the narrator finds two local drunkards "aristocratic" (Dovlatov, 2014, 40, 122) and spends a week drinking with one of them and claiming to be Pushkin and Baratynsky (Dovlatov, 2014, 119).

In some guides Dovlatov parodies Pushkin's features of which the poet remarked ironically such as (happy) laziness and light-heartedness (Schastlivoi leni verny syn, vsegda bespechnyi, ravnodushny...). There is genius of "pure learning" Mitrofanov who had read thousands books, but in his research paper wrote only the beginning of the first sentence "As we all know" and was too lazy to continue (Dovlatov, 2014, 46). There is also a comic version of the $19^{\text {th }}$ century gentilesse, Stasik Pototsky, who published seven "banal, ideologically sound and dull" stories, but in the preserve was able to "act out the duel scene in character" and click "his worn-down heels" in ladies' presence (Dovlatov, 2014, 50-52, 93).

Among the unsuitable servers of "the Pushkin cult", the most striking is Guryanov who in his student days became famous for declaring he had read "The tale of Ivan Onegin" (Dovlatov, 2014, 147). This is one of the few examples where Ekaterina Dovlatova had to use a linguacultural compensation and change "Dombrovsky" in the original to a play on words with Pushkin's work more familiar in the Anglophone world. In most other cases she preserved the original references and accompanied them with footnotes. In her interview, she explained that the authorial speech was the most difficult for translation but hearing her father's voice helped her (Stivers, 2014). She did succeed, which shows, for example, in the following rhythmic passage crucial for Dovlatov's vision of Pushkin: "What intrigued me most about Pushkin was his Olympian detachment. His willingness to accept and express any point of view. His invariable striving for the highest, utmost objectivity. <..> His literature is above morality. It transcends morality and even takes its place. His literature is akin to prayer, to nature" (Dovlatov, 2014, 57).

In his afterword to the book's American edition (also published by The New Yorker a week before the book came out), James Wood establishes the émigré ancestry for Dovlatov's protagonist in Nabokov's Timofey Pnin. The critic says that Pnin knows "this portable, internal, untouchable, undisappointable world to be the cosmos you carry inside you - the stories, the people, the memories, the anecdotes and jokes, even the very dates of one's national history; in short, the emigre's entire cultural formation" 
(Dovlatov, 2014, 150). However, the original Russian predecessor for Dovlatov's hero might be Pushkin's non-didactic, sometimes ironic but always sympathetic narrator Ivan Belkin, whose tales Dovlatov mentioned by no chance in a Guryanov anecdote described above.

Many scholars focused on the Russian literary heritage in Sergei Dovlatov's work, Pushkin and Chekhov being his most important "ancestors". Symbolically, at the 1999 Oxford conference Two Hundred Years of Pushkin, Ekaterina Young presented a paper "Dovlatov's Sanctuary and Pushkin", which she later included in her book Sergei Dovlatov and His Narrative Masks, the first English monograph study of Dovlatov's work. In her paper, Young shows that Dovlatov's laconic style, which spares epithets and prefers a variety of verbs to make the narrative more dynamic, was his conscious effort to "recuperate" Pushkin's tradition of Russian prose (Young, 2009, 127-130).

In Zapovednik Dovlatov paralleled the Soviet censorship and KGB surveillance (explicitly mentioned in his novel) with tsarist censorship and the Third Department surveillance of Pushkin times. He also continued the Russian postmodern effort of desovietizing Pushkin, started by Andrey Sinyavsky/Abram Terz in Strolls with Pushkin (Proguliki s Pushkinym published in London in 1975, translated into English in 1999) and Andrey Bitov in The Pushkin House (Pushkinsky Dom published in Ardis in 1978, translated into English in 1987). All three books are tributes to Pushkin's freedom of art. While Abram Terz's Strolls with Pushkin already found a direct response in American fiction - the protagonist in John Crowley's 2001 novel The Translator is a Russian dissident poet who grounds his American lectures on Terz's book, as the author explains in a footnote - Dovlatov's Pushkinian discourse is more disperse and is awaiting its resonance.

\section{Conclusion}

The response to Dovlatov's ludic literary discourse is likely to occur in American literature as his storytelling art is somewhat American in its nature. Dovlatov's friend and famous USbased scholar Alexander Genis argued that Dovlatov's Pushkinian style is unique for Russian literature and more typical for American prose, which should contribute to his translatability (Genis, 1998, 10). Prominent Russian Dovlatov scholar Igor Sukhikh mentioned his "PushkinianHemingwaysque intonation" (Sukhikh, 1996, 160). Popular Russian Canadian author David Bezmozgis read Dovlatov's story "The Colonel Says I Love You" for The New Yorker Fiction Podcast project, which aims to revive interest in the fiction published by this magazine. In an accompanying interview, Bezmozgis said that Dovlatov's humor and pseudo-autobiographic mode builds well into American tradition pronounced in such authors as Philip Roth (Bezmozgis, 2014).

David Bezmozgis belongs to a growing group of the young Russian American Anglophone authors who highly appreciate Dovlatov and might even participate in retranslations of his and other émigré works into English. Dovlatov's deceptively simple, humorous stories are truly humane and deeply rooted in Russian classics. The organic interaction of Russian and American traditions in Dovlatov's fiction secures its important position on the transcultural literary scene.

The Jubilee Boy, June 9, 1980. P. 39-47. Somebody's Death. October 19, 1981. P. 42-52. Straight Ahead. January 25, 1982. P. 35-41 My First Cousin. December 5, 1983. P. 50-58. The Colonel Says I Love You. May 5, 1986. P. 42-47. Uncle Aron. October 20, 1986 P. 40-41. Uncle Leopold. July 13, 1987 P. 25-30. Father. November 30, 1987 P. 34-36. The Photo Album. March 27, 1989 P. 43-47. Driving Gloves. May 8, 1989 P. 36-40. 


\section{References}

Bezmozgis, D. (2014) Reading Sergei Dovlatov. Available at: http://www.newyorker.com/podcast/ fiction/david-bezmozgis-reads-sergei-dovlatov

Dovlatov, S. (1989b) Driving Gloves. Tr. by A. W. Bouis. The New Yorker, May 8, 36-40.

Dovlatov, S. (1987a) Father. Tr. by A. Frydman. The New Yorker, November 30, 34-36.

Dovlatov, S. (1983) My First Cousin. Tr. by A. Frydman. The New Yorker, December 5, 50-58.

Dovlatov, S. (2014) Pushkin Hills. Berkeley: Counterpoint. 163 p.

Dovlatov, S. (1995) Sobranie Sochnenii [Collected Works] in 3 volumes. (2). St. Petersburg, Limbus Press, 383 p.

Dovlatov, S. (2011) The Suitcase. Tr. by A. W. Bouis. Berkeley: Counterpoint Press. 136 p.

Dovlatov, S. (1987b) Uncle Leopold. Tr. by A. Frydman. The New Yorker, July 13, 25-30.

Dovlatov. S. (1989b) The Photo Album. Tr. by A. W. Bouis. The New Yorker, March 27, 43-47

Fiene, D. M. (1984) Review of Sergei Dovlatov's The Compromise. Tr. Anne Frydman. NY: Alfred A. Knopf. 1983. The Slavic and East European Journal, 4 (28), 552-553.

Genis, A. (1998) Moloko, konechno, skislo, no... [The milk got sour, but...]. Interview by T.Vol'tskaya. In Literaturnaya gazeta [Literature Newspaper] 23, 10.

Praises for Sergei Dovlatov's Pushkin Hills (2013). Available at: http://www.almaclassics.com/ pushkin-hills-p-564-book.html (accessed 10 January 2016).

Stivers, V. (2014) Translating Pushkin Hills: An Interview with Katherine Dovlatov. The Paris Review. March 26. Available at: http://www.theparisreview.org/blog/2014/03/26/translating-pushkinhills-an-interview-with-katherine-dovlatov (accessed 10 January 2016).

Sukhikh, I. (1996) Sergei Dovlatov: vremya, mesto, sud'ba [Sergei Dovlatov: time, place, destiny]. St. Petersburg, Azbuka, 288 p.

Taplin Phoebe (2013). Review. Pushkin Hills by Sergei Dovlatov. Available at: The Guardian. www.theguardian.com/books/2013/oct/05/pushkin-hills-sergei-dovlatov-review (accessed 10 January 2016).

Wood, J. (2014) Afterword for Pushkin Hills. Berkeley: Counterpoint, 141-152.

Young, E. (2009) Sergei Dovlatov and His Narrative Masks. Evanston: Northwestern University Press, $271 \mathrm{p}$. 


\title{
Игровой литературный текст Сергея Довлатова
}

\section{в оригинале и переводе}

Е.М. Бутенина

Дальневосточный федеральный университет Россия, 690920, Владивосток, бухта Аякс, о. Русский

\begin{abstract}
Для современной мировой литературы характерно активное взаимодействие с русской классикой: это и романизированные биографии русских писателей, и модернизации, и другие аллюзивные формы. Больщую роль в формировании этого феномена сыграли русские эмигранты, чье тексты, пронизанные диалогом с родной словесностью, служили ее медиаторами в иноязычное пространство. Начатая в творчестве Владимира Набокова, эта традици была продолжена эмигрантами третьей волны:: Андреем Синявским/Абрамом Терием, Василием Аксеновым, Сергеем Довлатовым. Сергей Довлатов, как неоднократно отмечалось в американской прессе, достиг в США небывалого для автора-эмигранта успеха, поскольку при жизни писателя, с 1980 по 1989 год, в элитарном еженедельнике «Нью-Йоркер» было опубликовано десять его рассказов. Стиль Довлатова пришелся по вкусу литературным редакторам «Нью-Йоркера» во многом благодаря переводчииам Энн Фридман и Антонине Буа. Однако анализ перевода рассказов Довлатова, опубликованных в «Нью-Йоркере», показывает, что многие элементы его игрового литературного текста, составляющего одну из ключевых особенностей его (авто)мифотворческой поэтики, утрачены и в переводах Фридман, и в переводах Буа, хотя нередко подобную компрессию трудно объяснить культурологическими причинами. Перевод романа «Заповедник», выполненный дочерью писателя, Екатериной Довлатовой, демонстрирует большее внимание к оригиналу, что, наряду с популяризаџией писателя современными русско-американскими авторами, способствует возрождению интереса к нему в англоязычном мире. Органичное взаимодействие русской и американской литературных традищий в прозе Довлатова определяет ее важную роль в современном транскультурном диалоге.
\end{abstract}

Ключевые слова: третья волна эмиграции, Сергей Довлатов, Журнал «Нью-Йоркер», Энн Фридман, Антонина Буа, Екатерина Довлатова.

Научная специальность: 10.00 .00 - филологические науки. 